Kashuba, V., Andrieieva, O., Hakman, A., Grygus, I., Smoleńska, O., Ostrowska, M., Napierała, M., Hagner-Derengowska, M., Muszkieta, R., \& Zukow, W. (2021). Impact of Aquafitness Training on Physical Condition of Early Adulthood Women. Teoriâ ta Metodika Fizičnogo Vihovannâ, 21(2), 152-157. https://doi.org/10.17309/tmfv.2021.2.08

ISSN 1993-7989 (print). ISSN 1993-7997 (online)

\title{
IMPACT OF AQUAFITNESS TRAINING ON PHYSICAL CONDITION OF EARLY ADULTHOOD WOMEN
}

\author{
Vitalii Kashuba $^{1 \mathrm{ABCD}}$, Olena Andrieieva ${ }^{1 \mathrm{ABCD}}$, Anna Hakman ${ }^{2 \mathrm{ABCD}}$, Igor Grygus ${ }^{3 \mathrm{AD}}$, \\ Olga Smoleńska ${ }^{4 \mathrm{DE}}$, Małgorzata Ostrowska ${ }^{4 \mathrm{DE}}$, Marek Napierała ${ }^{5 \mathrm{DE}}$, Magdalena \\ Hagner-Derengowska $^{4 \mathrm{DE}}$, Radosław Muszkieta ${ }^{4 \mathrm{DE}}$, Walery Zukow ${ }^{4 \mathrm{DE}}$
}

${ }^{1}$ National University of Physical Education and Sport of Ukraine

${ }^{2}$ Yuriy Fedkovych Chernivtsi National University

${ }^{3}$ National University of Water and Environmental Engineering

${ }^{4}$ Nicolaus Copernicus University

${ }^{5}$ University of Economy

Authors' Contribution: A - Study design; B - Data collection; C - Statistical analysis; D - Manuscript Preparation; E - Funds Collection

Corresponding Author: Radosław Muszkieta, E-mail: muszkieta@umk.pl

Accepted for Publication: May 18, 2021

Published: June 25, 2021

\section{DOI: 10.17309/tmfv.2021.2.08}

\begin{abstract}
Background. The physical benefits of fitness for middle-aged women are well-known. Unlike the usual training sessions, aquafitness occupies a special place among the types of health-related exercise training. Its health-enhancing effect results from the activation of the body's functional systems, the gravitational unloading of the musculoskeletal system, high energy expenditures, and overall body hardening effect.

The objective of this study was to evaluate the health-enhancing effects of an aquafitness program on the functional indicators and physical fitness of early adulthood women.

Materials and methods. Theoretical analysis and generalization of scientific and methodological literature, anthropometric techniques, pedagogical methods, and methods of mathematical statistics were used. The functional status of the body was assessed with the indices characterizing the function of the cardiorespiratory system, which are commonly used. The study was conducted at the Sport Life fitness club, Chernivtsi. The study involved 48 women aged 21-31 with an average age of 26.3 years. The subjects took part in a six-month aquafitness program consisting of 60 -min sessions, three times a week. The program was developed by the authors and included aquatic stretching, body shaping and bodybuilding exercise, aquadance, aquatic gymnastics, and aqua tae-bo.

Results. After participation in the exercise program: vital capacity increased from $45.96 \pm 4.69$ to $48.88 \pm 0.68$; strength index increased from $35.80 \pm 1.07$ to $43.26 \pm 0.71$; Robinson's index increased from $85.72 \pm 12.34$ to $89.63 \pm 10.11$; Shtange test increased from $30.28 \pm 10.32$ to $37.78 \pm 12.34$; Hench test changed from $16.48 \pm 4.24$ to $25.19 \pm 4.58$; Kerdo index decreased from $5.23 \pm 0.74$ to $0.88 \pm 0.38$; and Rufier's test decreased from $12.21 \pm 4.26$ to $8.03 \pm 2.14$. The assessment of somatic health of the women showed a significant improvement $(\mathrm{p}<0.05)$. Positive changes in the autonomic system were detected.

Conclusion. The developed aquafitness program can be an effective tool for health improvement and body weight management in early adulthood women.

Keywords: women, early adulthood, physical condition, aquafitness.
\end{abstract}

\section{Introduction}

In today's environment, interest in fitness training is constantly growing (Bocalini et al., 2008; Kenny et al., 2011; Persaki et al., 2016). Physical activity allows you to stay

(c) Kashuba, V., Andrieieva, O., Hakman, A., Grygus, I., Smoleńska, O., Ostrowska, M., Napierała, M.,

Hagner-Derengowska, M., Muszkieta, R., Zukow, W., 2021. in good shape, to strengthen and maintain health, and to be confident, and thus to lead a full life, to be in harmony with yourself and the world around you. In this situation, the range of means of health-enhancing physical activities are being expanded and new fitness programs and technologies are being developed (AEA, 2010; Andrieieva et al., 2019; Saavedra et al., 2007; Yelizarova et al., 2020). 
Currently, assessment of the level of physical condition (LPC) in early adulthood women and ways to improve it are the subject of numerous studies (AEA, 2010; Andrieieva et al., 2020; Avelar et al., 2010; Bocalini et al., 2010; Broman et al., 2006). An analysis of recent publications about the impact of fitness training on a woman's body showed that the development of the field of recreation and health-enhancing physical activities now cannot do without a scientifically sound implementation of modern innovative technologies in the fitness industry (Colado et al., 2009; Kashuba, Andrieieva, 2006; Salnykova et al., 2017; Yarmak et al., 2017; Gozhenko et al., 2018a; Gozhenko et al., 2018b).

Researchers on physical education believe that the amount of physical activity (PA) per week should be 6-10 hours for people over 25 years, 10-14 hours for people aged 18-25, 1421 hours for schoolchildren, and 21-28 hours for preschoolers (Garber et al., 2011; Schuch, et al., 2014). The WHO data demonstrated that adults aged 18-64 years should do at least 150300 minutes of moderate-intensity aerobic physical activity; or at least 75-150 minutes of vigorous-intensity aerobic physical activity; or an equivalent combination of moderate- and vigorous-intensity activity throughout the week (WHO, 2020).

As noted by many experts in the field (Drozdovska et al., 2020; Rýzková et al., 2018; Goncharova et al., 2020; Khimenes et al., 2016, Petrenko, et al., 2016), it is crucial to consider such factors as professional activity and health status when designing health-enhancing exercise routines for early adulthood women. Furthermore, the methods of exercise prescription for women should be based on the principle of biological rationale that determined by the characteristics of a woman's body. Health-enhancing programs for women differ not only in the parameters of physical exercise, but also in the objectives and effectiveness. The studies of the impact of various exercise programs are relevant and the least developed to date (Cadore et al., 2011; Hakman et al., 2019; Balatska et al., 2020).

Health-enhancing aquafitness programs are the most popular among women. It has been reported (Urbanová et al., 2010; Kashuba et al., 2020, Yarmak et al., 2018) that water exercise can positively affect the functional state of the musculoskeletal system, development of the respiratory system, and psycho-emotional state. Furthermore, recently there has been observed a growing interest of women interest in aquafitness as a means to recover strength, maintain good athletic performance, and health.

Nevertheless, despite the significant amount of data on the effectiveness of aquatic exercise training using recreational swimming, there are virtually no studies for assessing the impact of training programs involving the use of innovative aquafitness exercise for women 21-35 years with average physical condition.

The objective of this study was to evaluate the health-enhancing effects of an aquafitness program on the functional indicators and physical fitness of early adulthood women.

\section{Materials and methods}

\section{Study participants}

The study involved 48 women aged 21-31 with an average age of 26.3 years, who had different exercise experience. Before the study, none of the subjects were engaged in aquafitness training. All the women were healthy. During the study, the subjects were engaged only in aquafitness training and did not perform any other physical activity. Prior the beginning of the study, participants completed a questionnaire for health history and physical activity, and signed informed consent forms.

\section{Study organization}

Vital capacity of the lungs was measured with a dry spirometer according to the commonly used procedures. Hand muscle strength was assessed by the measurement of grip strength with a hand dynamometer. In addition, depending on the objectives, common indicators of the morphofunctional status of the body were used such as Kerdo index, Shtange test, Ruffier test, Hench test, strength index, vital capacity $(\mathrm{mL} / \mathrm{kg})$, index of functional changes (by $\mathrm{R}$. Bayevsky), and Quetelet index.

Index of functional changes by R. Bayevsky were calculated using the following equation:

IFC (arb. un.) $=0.011 \times \mathrm{HR}+0.014 \times \mathrm{BPsy}+$ $0.008 \times \mathrm{BPdi}+0.014 \times \mathrm{A}+0.009 \times \mathrm{BW}-0.009 \times \mathrm{H}-0.27$, where HR is heart rate in bpm, BPsy is systolic and BPdi is diastolic blood pressure in $\mathrm{mmHg}, \mathrm{A}$ is age in years, $\mathrm{BW}$ is body weight in $\mathrm{kg}$, and $\mathrm{H}$ is height in $\mathrm{cm}$. The functional adaptation of the cardiovascular system in adult persons is then classified as follows: satisfactory adaptation $<2.59$, tension of adaptation mechanisms - 2.60-3.09, unsatisfactory adaptation - 3.10-3.49, and failure of adaptation - 3.50.

To indirectly assess body fat, the Quetelet index calculated as a ratio between body weight (in g) and height (in $\mathrm{cm}$ ) was used.

The study was conducted at the Sport Life fitness club, Chernivtsi. The subjects took part in a six-month aquafitness program consisting of 60-minute sessions, three times a week. The program was developed by the authors and included aquatic stretching, body shaping and bodybuilding exercise, aquadance, aquatic gymnastics, and aqua tae-bo. The training program included aerobic, strength, and mixed type exercises, which have diverse effects on the body systems of the subjects. The water temperature was kept at $28^{\circ} \mathrm{C}$. When designing the program routine, we followed the recommendations of the authors of previous studies (Bocalini et al., 2010; Khimenes et al., 2016; Yarmak et al., 2017). The training session had the traditional structure and consisted of warm-up, main part, and cool-down. The warm-up part included basic movements and combinations for warming up, pre-workout stretching and cardiorespiratory warm-up (e.g., running, punches, kicks, and jumps in various directions and planes). The main part consisted of strength endurance exercises for major muscle groups (exercises of aqua aquatic stretching, body shaping and bodybuilding exercise, aquadance, aquatic gymnastics, and aqua tae-bo) performed at moderate intensity in the aerobic training zone. The intensity of exercise was corresponding to the target heart rate zone for health-enhancing training for this gender and age group. The cool-down phase consisted of exercises to restore breathing and relaxation.

\section{Statistical analysis}

The results of the study were subjected to statistical data analysis using conventional tools of Statistica 10.0 statistical software (StatSoft, Inc., USA). With an average sample size 
$(30 \leq \mathrm{n} \leq 100)$, the normality of the distribution was tested by several methods including the Shapiro-Wilk test as well as asymmetry and excess kurtosis. One-dimensional statistical analysis, which involved calculating the arithmetic mean (M) and standard error (SE), was applied in the research. The significance of the difference ( $p$ ) according to Student's t-test (t) was used to assess the effects of exercise program on the physical condition of participants. The significance for all statistical tests was set at $\mathrm{p} \leq 0.05$.

\section{Results}

To study the health-enhancing effects of aquafitness on the body of early adulthood women, we used the criteria of effectiveness of health-enhancing physical exercise including such important ones as an increase in the functional reserves of the body. Thus, after the implementation of the developed health-enhancing program of aquafitness classes for early adulthood women, its effectiveness was evaluated by the comparative assessment of the functional status of participants at the beginning and at the end of the study.

Assessment of the women showed that they had an average or below average level of most indicators of morphofunctional status and physical condition at the beginning of the study (Table 1). Therefore, all subjects were allowed to participate in the exercise program without significant restrictions.

The data presented in the Table 1 demonstrated a positive effect of participation in the exercise program on the pa-

Table 1. Changes in somatic health of early adulthood women participated in the aquafitness program $(n=48)$

\begin{tabular}{lrrrc}
\hline \multirow{2}{*}{\multicolumn{1}{c}{ Parameter }} & \multicolumn{4}{c}{ Statistics } \\
\cline { 2 - 5 } & at the beginning & at the end \\
\cline { 2 - 5 } & \multicolumn{1}{c}{$\mathbf{M}$} & \multicolumn{1}{c}{ SE } & M & \multicolumn{1}{c}{ SE } \\
\hline Vital capacity, $\mathrm{mL} \cdot \mathrm{kg}^{-1}$ & 45.96 & 4.69 & 48.88 & $0.68^{*}$ \\
Strength index, \% & 35.80 & 1.07 & 43.26 & $0.71^{*}$ \\
Robinson index, arb. units & 85.72 & 12.34 & 89.63 & 10.11 \\
Shtange test, s & 30.28 & 10.32 & 37.78 & 12.34 \\
Hench test, s & 16.48 & 4.24 & 25.19 & $4.58^{*}$ \\
Kerdo index, arb. un. & 5.23 & 0.74 & 0.88 & $0.38^{*}$ \\
Ruffier test, arb. un. & 12.21 & 1.26 & 8.03 & $2.14^{*}$ \\
\hline
\end{tabular}

Note: ${ }^{\star}-\mathrm{p}<0.05$

rameters of somatic health of early adulthood women. These findings indicate the need of early adulthood women for the training of the respiratory system, which can be achieved by including special exercises in aquafitness training. Results of the Shtange and Hench tests also confirmed improved function of the respiratory system after the end of the program.

The strength index was increased from $35.80 \pm 1.07 \%$ to $43.26 \pm 0.71 \%$ at the end of the study.

It is known that prescribing the appropriate volume of exercise should be based on the data of the functional assessment of the cardiovascular system. For this purpose, the Robinson index was used. This index amounted to $85.72 \pm$ $12.34 \mathrm{arb}$. un. at the beginning of the study. This corresponds to an average level and confirms the fact that there were no contraindications related to health status for participation in the health-enhancing exercise program. After the aquafitness training, the Robinson index was found to improve to 89.63 \pm 10.11 arb. un. that corresponds to a high level of function of cardiovascular system.

It is known that the ratio of heart rate to blood pressure remains constant in the normal conditions. Based on this pattern, the Kerdo index was proposed for assessing the state of the autonomic nervous system. The values of this index greater than zero indicate the sympathetic predominance in the cardiovascular regulation, the values less than zero indicate the parasympathetic predominance, and the value that is equal to zero indicates functional equilibrium. The average value of the Kerdo index was $5.23 \pm 0.74$ at the beginning and changed to $0.88 \pm 0.38$ after participation in the exercise program.

Another measure used to evaluate the effectiveness of our program was the Ruffier index. An average value of the Ruffier index (12.21 \pm 1.26 arb. un.) at the beginning of the study indicates a low adaptation of the cardiovascular system to the exercise in the absence of pathology. This may be explained by hypodynamia and a sedentary lifestyle. After participation in the program, the Ruffier index improved by $4.18 \mathrm{arb}$. un.

The normal range of the index is $325-365 \mathrm{~g} / \mathrm{cm}$ for women of this age group. According to the Quetelet index, 70.8\% of subjects had a normal body weight, $20.8 \%$ were overweight, and $8.3 \%$ were obese at the beginning of the study. The values of the Quetelet index improved after exercise training: 79.2\% of women had a normal body weight and only $20.8 \%$ (5 subjects) were overweight.

The functional assessment of the cardiovascular system was conducted using the following parameters: heart rate at relative rest, blood pressure, and adaptive capacity (AC) of the circulatory system according to R.Bayevsky (Table 2). Heart rate and blood pressure values of all the subjects were in the normal range for this age group. At the end of the study, the group average value of the IFC was changed from $2.72 \pm 1.01$ to $2.55 \pm 0.92$. The changes in the distribution of early adulthood women by the index of functional changes is shown in Table 2.

The positive changes in the physical condition of early adulthood women (Table 3) confirm the effectiveness of the training program.

Table 2. Distribution of early adulthood women by the index of functional changes (by R. Bayevsky), \% $(\mathrm{n}=48)$

\begin{tabular}{|c|c|c|c|}
\hline Group & Level of adaptation & $\begin{array}{c}\text { at the } \\
\text { beginning }\end{array}$ & at the end \\
\hline I & Satisfactory adaptation & 8.33 & 62.50 \\
\hline II & Tension of adaptation mechanisms & 75.00 & 33.33 \\
\hline III & Unsatisfactory adaptation & 12.50 & 4.17 \\
\hline IV & Failure of adaptation & 4.17 & 0.0 \\
\hline
\end{tabular}

Table 3. Distribution of early adulthood women by the level of physical condition by O. Pirogova, $\%(n=48)$

\begin{tabular}{lcc}
\hline \multicolumn{1}{c}{ Level of physical condition } & $\begin{array}{c}\text { at the } \\
\text { beginning }\end{array}$ & at the end \\
\hline Low & 4.17 & 0.0 \\
Lower than average & 25.00 & 4.17 \\
Average & 29.17 & 12.50 \\
Higher than average & 25.00 & 50.00 \\
High & 16.67 & 33.33 \\
\hline
\end{tabular}


Kashuba, V., Andrieieva, O., Hakman, A., Grygus, I., Smoleńska, O., Ostrowska, M., Napierała, M., Hagner-Derengowska, M., Muszkieta, R., \& Zukow, W. (2021). Impact of Aquafitness Training on Physical Condition of Early Adulthood Women

Table 4. Changes in physical fitness of early adulthood women participated in the aquafitness program $(n=48)$

\begin{tabular}{lccccc}
\hline \multirow{2}{*}{ Test } & \multicolumn{4}{c}{ Statistics } \\
\cline { 2 - 6 } & \multicolumn{1}{c}{ at the beginning } & \multicolumn{2}{c}{ at the end } \\
\cline { 2 - 6 } & $\mathbf{M}$ & SE & M & SE \\
\hline Standing long jump, cm & 148.7 & 5.6 & 158.4 & $6.1^{*}$ \\
$\begin{array}{l}\text { Sit-up test for 30 s, number of } \\
\text { reps }\end{array}$ & 25.7 & 2.1 & 42.3 & $4.6^{*}$ \\
$\begin{array}{l}\text { Sit and reach flexibility test, cm } \\
\text { Push-up test, number of push- }\end{array}$ & 5.08 & 1.2 & 16.4 & $1.4^{*}$ \\
ups performed during 30 s & 11.5 & 2.1 & 15.9 & $4.2^{*}$ \\
\hline
\end{tabular}

Note: ${ }^{\star}-\mathrm{p}<0.05$

The comparative assessment of physical fitness and physical condition of the subjects demonstrated a significant increase in the parameters of physical fitness in the studied sample of women compared to the beginning of the aquafitness program (Table 4). For example, the average result of the women in the standing long jump test that measures explosive force production of the thigh muscles was $148.7 \pm 5.6 \mathrm{~cm}$ at the beginning of the study. After participation in the aquafitness training, the indicator of explosive power improved by $9.7 \mathrm{~cm}$.

The strength endurance of the abdominal muscles significantly improved after participation in the aquafitness program compared to the beginning of the study. Furthermore, their flexibility was significantly improved. Similar changes were observed in the number of push-ups performed during $30 \mathrm{~s}$ (push-up test).

Taken together, these results indicate that the aquafitness program had a positive effect on the physical fitness of all the women, thus demonstrating the effectiveness of the developed program of water exercise.

\section{Discussion}

The analysis of special literature showed that exercise in the aquatic environment such as aquafitness and its varieties (aquatic stretching, body shaping and bodybuilding exercise, aquadance, aquatic gymnastics, and aqua tae-bo) are among the most popular types of fitness training because of their availability, emotionality, and effectiveness. However, when analyzing available literature there are few data on health-enhancing effects of aqua fitness in early adulthood women.

The data of this study on the positive effects of aquafitness training on a woman's body are in agreement with previous findings (Bocalini et al., 2010; Goncharova et al., 2020). Assessment of parameters of somatic health of women aged 21-31 years showed a significant improvement $(\mathrm{p}<0.05)$ in functional status of the cardiorespiratory system and autonomic nervous system, anthropometry measurements, working capacity and physical condition.

The beneficial effects of aquatic exercise training on the functional state of the cardiovascular system of women was further confirmed, including the economization of the functions and increase in the level of functional fitness of the cardiovascular system. The knowledge on the health-improving potential of innovative aquafitness exercise was further advanced.

The results of breath holding tests demonstrated an improvement in the function of the respiratory system of early adulthood women at the end of the program that resulted from the increased body's ability to utilize oxygen.

\section{Conclusion}

Our data extend and supplement the knowledge on the positive effects of aquafitness on the body of early adulthood women manifested as significantly improved adaptation mechanisms and physical condition.

Positive changes in body weight of the women also observed that is the main reason for choosing aquafitness training as a recreational and health-enhancing type of physical activity. The aquafitness training also stabilized the values of functional indicators of the cardiovascular system of early adulthood women. The developed program may contribute to health improvement and body weight management of early adulthood women.

Further research should focus on the development of science-based physical exercise training programs for women who want to improve their physical condition through the use of novel training equipment.

\section{Conflict of interest}

The authors declare that there is no conflict of interest that could be perceived as interfering with publication of the article.

\section{Funding sources}

This study has not received any financial support from any government, community or commercial organization.

\section{Ethical Approval}

All procedures performed in studies involving human participants were in accordance with the ethical standards of the institutional and/or national research committee and with the 1964 Helsinki declaration and its later amendments or comparable ethical standards.

\section{References}

Bocalini, D.S., Serra, A.J., Murad, N., \& Levy, R. I. (2008). Water- versus land-based exercise effects on physical fitness in older women. Geriatrics Gerontology International, 8(4), 265-271. https://doi.org/10.1111/j.1447-0594.2008.00485.x

Kenny, W.L., Wilmore, J.H., \& Costill, D.L. (2015). Physiology of sport and exercise $\left(6^{\text {th }}\right.$ ed.). Human Kinetics.

Persaki, D., Apostolidis, N., \& Soultanakis, H. (2016). Aqua Pilates versus Land Pilates: Physical fitness outcomes. Journal of Physical Education and Sport, 16(2), 573-578. https://doi.org/10.7752/jpes.2016.02090

AEA. (2010). Aquatic fitness professional manual (6th. ed.). Human Kinetics: Champaign, IL.

Andrieieva, O., Hakman, A., Kashuba, V., Vasylenko, M., Patsaliuk, K., Koshura, A., \& Istyniuk, I. (2019). Effects of physical activity on aging processes in elderly persons. Journal of Physical Education and Sport, 19(4), 1308-1314. https://doi.org/10.7752/jpes.2019.s4190

Saavedra, J. M., de la Cruz E., Escalante, Y., \& Rodríguez, F. A. (2007). Influence of a medium-impact aquaerobic 
program on health-related quality of life and fitness level in healthy adult females. Journal of Sports Medicine and Physical Fitness, 47(4), 468-474.

Yelizarova, O, Stankevych, T, Parats, A, Antomonov, M, Polka, N, \& Hozak, S (2020). Specific features of the ukrainian urban adolescents' physical activity: A cross-sectional study. Journal of Environmental and Public Health, 2020, Art. ID 3404285. https://doi.org/10.1155/2020/3404285

Andrieieva, O., Yarmak, O., Kashuba, V., Drozdovska, S., Gineviciene, V., Blagii, O., \& Akimova-Ternovska, M. (2020). Efficiency of a Combined Fitness Program for Improving Physical Condition in Young Women. Teoriâ ta Metodika Fizičnogo Vihovannâ, 20(4), 195-204. https://doi.org/10.17309/tmfv.2020.4.01

Avelar, N. C., Bastone, A. C., Alcântara, M. A., \& Gomes, W. F. (2010). Effectiveness of aquatic and non-aquatic lower limb muscle endurance training in the static and dynamic balance of elderly people. Brazilian Journal of Physical Therapy, 14(3), 229-236.

Bocalini, D. S., Serra, A. J., Rica, R. L., \& Santos, L. D. (2010). Repercussions of training and detraining by water-based exercise on functional fitness and quality of life: a short-term follow-up in healthy older women. Clinics, 65(12), 1305-1309. https://doi.org/10.1590/s1807-59322010001200013

Broman, G., Quintana, M., Lindberg, T., Jansson, E., Kaijser, L. (2006). High intensity deep water training can improve aerobic power in elderly women. European Journal of Applied Physiology, 98(2), 117-123. https://doi.org/10.1007/s00421-006-0237-2

Colado, J.C., Triplett, N.T., Tella, V., Saucedo, P., \& Abellan, J. (2009). Effects of aquatic resistance training on health and fitness in postmenopausal women. European Journal of Applied Physiology, 106(1), 113-122. https://doi.org/10.1007/s00421-009-0996-7

Kashuba, V., Andrieieva, O. (2006). The trends in recreational activity of different groups of Ukrainians. Research year book. Studies in physical education and sport, 12(1), 145-147.

Salnykova, S., Hruzevych, I., Bohuslavska, V., Nakonechnyi, I., Kyselytsia, O., Pityn, M. (2017). Combined application of aquafitness and the endogenous-hypoxic breathing technique for the improvement of physical condition of 30-49-year-old women. Journal of Physical Education and Sport, 17(4), 2544-2552. https://doi.org/10.7752/jpes.2017.04288

Yarmak, O., Blagii, O., Palichuk, Y., Hakman, A., Balatska, L., Moroz, O., \& Galan, Y. (2018). Analysis of the factor structure of the physical condition of girls 17-19 yearold. Journal of Human Sport and Exercise, 13(2proc), S259-S268. https://doi.org/10.14198/jhse.2018.13.Proc2.11

Gozhenko, A., Biryukov, V., Gozhenko, O., \& Zukow, W. (2018a). Health as a space-time continuum. Journal of Education, Health and Sport, 8(11), 763-777. https://doi.org/10.5281/zenodo.2657000

Gozhenko, A., Biryukov, V., Muszkieta, R., \& Zukow, W. (2018b). Physiological basis of human longevity: the concept of a cascade of human aging mechanism. Collegium antropologicum, 42(2), 139-146.

Garber, C.E., Blissmer, B., Deschenes, M.R., Franklin, B.A., Lamonte, M.J., Lee, I.M., Nieman, D.C., \& Swain, D.P. (2011). American College of Sports Medicine position stand. Quantity and quality of exercise for developing and maintaining cardiorespiratory, musculoskeletal, and neuromotor fitness in apparently healthy adults: guidance for prescribing exercise. Medicine and Science in Sports and Exercise, 43(7), 1334-1359. https://doi.org/10.1249/MSS.0b013e318213fefb

Schuch, F. B., Pinto, S. S., Bagatini, N. C., Zaffari, P., Alberton, C.L., Cadore, E. L., Silva, R. F., \& Kruel, L. F. M. (2014). Water-based exercise and quality of life in women: The role of depressive symptoms. Women \& Health, 54(2), 161-175. https://doi.org/10.1080/03630242.2013.870634

World Health Organization (2020). Guidelines on physical activity and sedentary behaviour. Geneva: World Health Organization. https://apps.who.int/iris/bitstream/hand le/10665/336656/9789240015128-eng.pdf

Drozdovska, S., Andrieieva, O., Yarmak, O., \& Blagii, O. (2020). Personalization of health-promoting fitness programs for young women based on genetic factors. Journal of Physical Education and Sport, 20, 331-337. https://doi.org/10.7752/jpes.2020.s1046

Rýzková, E., Labudova, J., Grznár, L., Šmída, M. (2018). Effects of aquafitness with high intensity interval training on physical fitness. Journal of Physical Education and Sport, 18(1), 373-381. https://doi.org/10.7752/jpes.2018.s151

Goncharova, N., Kashuba, V., Tkachova, A., Khabinets, T., Kostiuchenko, O., \& Pymonenko, M. (2020). Correction of postural disorders of mature age women in the process of aqua fitness taking into account the body type. Teoriâ $t a$ Metodika Fizičnogo Vihovannâ, 20(3), 127-136. https://doi.org/10.17309/tmfv.2020.3.01

Khimenes, K., Lynets, M., Briskin, Y., Pityn, M., \& Galan, Y. (2016). Improvement of sportsmen physical fitness during previous basic training (based on sport orienteering material). Journal of Physical Education and Sport, 16(2), 392-396. https://doi.org/10.7752/jpes.2016.02061

Petrenko, N. V. (2013). The dynamics of physical and mental health of students of economic specialties in the course of employment aqua. Pedagogics, psychology, medicalbiological problems of physical training and sports, 17(11), 67-71. https://doi.org/10.6084/m9.figshare.817928

Cadore, E.L., Pinto, R.S., Alberton, C.L., Pinto, S.S., Lhullier, F.L.R., Tartaruga, M.P., Correa, C.S., Almeida, A.P.V., Silva E.M., Laitano, O., \& Kruel, L.F.M. (2011). Neuromuscular economy, strength, and endurance in healthy elderly men. The Journal of Strength \& Conditioning Research, 25(4), 997-1003. https://doi.org/10.1519/JSC.0b013e3181d650ba

Hakman, A., Andrieieva, O., Kashuba, V., Omelchenko, T., Carp, I., Danylchenko, V., \& Levinskaia, K. (2019). Technology of planning and management of leisure activities for working elderly people with a low level of physical activity. Journal of Physical Education and Sport, 19(6), 2155-2166. https://doi.org/10.7752/jpes.2019.s6324

Balatska, L., Liasota, T., Nakonechnyi, I., Hakman, A., Bezverkhnia, H., Kljus, O., Osadchenko, T., \& Semenov, A. (2020). Motor activity of different social groups. Riga, Latvia: Baltija Publishing.

Urbanová, M., \& Labudová, J. (2010). The main motivational factors for doing aqua fitness of Slovak women. Sport Science Review, 19(3-4), 209-216. https://doi.org/10.2478/v10237-011-0026-7

Kashuba, V., Tomilina, Y., Byshevets, N., Khrypko, I., Stepanenko, O., Grygus, I., Smoleńska, O., \& Savliuk, S. (2020). Impact of Pilates on the Intensity of Pain in the Spine of Women of the First Mature age. Teoriâ ta Metodika Fizičnogo Vihovannâ, 20(1), 12-17. https://doi.org/10.17309/tmfv.2020.1.02 
Kashuba, V., Andrieieva, O., Hakman, A., Grygus, I., Smoleńska, O., Ostrowska, M., Napierała, M., Hagner-Derengowska, M., Muszkieta, R., \& Zukow, W. (2021). Impact of Aquafitness Training on Physical Condition of Early Adulthood Women

\title{
ВПЛИВ ТРЕНУВАНЬ 3 АКВАФІТНЕСУ НА ФІЗИЧНИЙ СТАН ЖІНОК РАННЬОГО ЗРІЛОГО ВІКУ
}

\author{
Віталій Кашуба $^{1 A B C D}$, Олена Андрєєва ${ }^{1 \mathrm{ABCD}}$, Анна Гакман ${ }^{2 \mathrm{ABCD}}$, Ігор Григус ${ }^{3 \mathrm{AD}}$, Ольга \\ Смоленська ${ }^{4 \mathrm{DE}}$, Малгожата Островська $^{4 \mathrm{DE}}$, Марек Наперала $^{5 \mathrm{DE}}$, \\ Магдалена Хагнер-Деренговська ${ }^{4 \mathrm{DE}}$, Радослав Мушкєта ${ }^{4 \mathrm{DE}}$, Валерій $Ж у к о в^{4 \mathrm{DE}}$
}

\author{
${ }^{1}$ Національний університет фізичного виховання та спорту України \\ ${ }^{2}$ Чернівецький національний університет імені Юрія Федьковича \\ ${ }^{3}$ Національний університет водного господарства та природокористування \\ ${ }^{4}$ Університет Миколи Коперника \\ ${ }^{5}$ Університет економіки \\ Авторський вклад: А - дизайн дослідження; В - збір даних; C - статаналіз; D - підготовка рукопису; Е - збір коштів \\ Реферат. Стаття: 6 с., 4 табл., 30 джерел.
}

Метою цього дослідження було оцінити оздоровчий вплив програми аквафітнесу на функціональні показники та фізичну підготовленість жінок раннього зрілого віку.

Матеріали і методи. Використовувалися теоретичний аналіз та узагальнення науково-методичної літератури, антропометричні прийоми, педагогічні методи та методи математичної статистики. Функціональний стан організму оцінювали за загальновживаними показниками, що характеризують функцію кардіореспіраторної системи. Дослідження проводилось у фітнес-клубі Sport Life, м. Чернівці. У дослідженні взяли участь 48 жінок у віці 21-31 років із середнім віком 26,3 року. Випробовувані брали участь у шестимісячній програмі аквафітнесу, яка складалася із 60-хвилинних занять тричі на тиждень. Програма була розроблена авторами і включала водне розтягування, формування тіла та вправи для бодібілдингу, акваданс, водну гімнастику та аква-тае-бо.
Результати. Після участі у програмі вправ: життєва ємність зросла 3 45,96 \pm 4,69 до 48,88 $\pm 0,68$; показник міцності збільшився з 35,80 \pm 1,07 до 43,26 \pm 0,71; Індекс Робінсона зріс з 85,72 $\pm 12,34$ до 89,63 \pm 10,11; Тест Штанге збільшився з 30,28 $\pm 10,32$ до $37,78 \pm 12,34$; Тест Генча змінено з 16,48 $\pm 4,24$ на 25,19 $\pm 4,58$; Індекс Кердо зменшився $35,23 \pm 0,74$ до $0,88 \pm 0,38$; а тест Руф'єра зменшився з $12,21 \pm 4,26$ до $8,03 \pm 2,14$. Оцінка соматичного здоров’я жінок показала значне поліпшення $(\mathrm{p}<0,05)$. Виявлено позитивні зміни у вегетативній системі.

Висновок. Розроблена програма аквафітнесу може бути ефективним інструментом для поліпшення здоров'я та управління масою тіла у жінок раннього зрілого віку.

Ключові слова: жінки, ранній зрілий вік, фізичний стан, аквафітнес.

\section{Information about the authors:}

Kashuba Vitalii: kashubavo@gmail.com; https://orcid.org/0000-0001-6669-738X; Department biomechanics and sport metrology, National University of Ukraine on Physical Education and Sport, Fizkultury St, 1, Kyiv, 03150, Ukraine.

Andrieieva Olena: andrieieva@gmail.com; https://orcid.org/0000-0002-2893-1224; Department biomechanics and sport metrology, National University of Ukraine on Physical Education and Sport, Fizkultury St, 1, Kyiv, 03150, Ukraine.

Hakman Anna: hakman@gmail.com; https://orcid.org/0000-0002-7485-0062; Department biomechanics and sport metrology, Yuriy Fedkovych Chernivtsi National University, Kotsjubynskyi Str, 2, Chernivtsi, 58012, Ukraine.

Grygus Igor: grigus03@gmail.com; https://orcid.org/0000-0003-2856-8514; Institute of Health, National University of Water and Environmental Engineering, Soborna St, 11, Rivne, 33028, Ukraine.

Smoleńska Olga: smolenska@umk.pl; https://orcid.org/0000-0002-2517-9081; Faculty of Earth Sciences and Spatial Management, Nicolaus Copernicus University, Lwowska St, 1, Torun, 87-100, Poland.

Ostrowska Małgorzata: ostrowska@umk.pl; https://orcid.org/0000-0002-3377-2950; Faculty of Earth Sciences and Spatial Management, Nicolaus Copernicus University, Lwowska St, 1, Torun, 87-100, Poland.

Napierała Marek: napierala@wsg.pl; https://orcid.org/0000-0002-9416-502X; Collegium of Medical Sciences, University of Economy, Garbary St, 2, Bydgoszcz, 85-229, Poland.

Hagner-Derengowska Magdalena: hagnerderengowska@umk.pl; https://orcid.org/0000-0002-7535-7624; Faculty of Earth Sciences and Spatial Management, Nicolaus Copernicus University, Lwowska St, 1, Torun, 87-100, Poland.

Muszkieta Radosław: muszkieta@umk.pl; https://orcid.org/0000-0001-6057-1583; Faculty of Earth Sciences and Spatial Management, Nicolaus Copernicus University, Lwowska St, 1, Torun, 87-100, Poland.

Zukow Walery: zukow@umk.pl; https://orcid.org/0000-0002-7675-6117; Faculty of Earth Sciences and Spatial Management, Nicolaus Copernicus University, Lwowska St, 1, Torun, 87-100, Poland.

Cite this article as: Kashuba, V., Andrieieva, O., Hakman, A., Grygus, I., Smoleńska, O., Ostrowska, M., Napierała, M., HagnerDerengowska, M., Muszkieta, R., \& Zukow, W. (2021). Impact of Aquafitness Training on Physical Condition of Early Adulthood Women. Teoriâ ta Metodika Fizičnogo Vihovannâ, 21(2), 152-157. https://doi.org/10.17309/tmfv.2021.2.08

Received: 13.04.2021. Accepted: 18.05.2021. Published: 25.06.2021

This work is licensed under a Creative Commons Attribution 4.0 International License (http://creativecommons.org/licenses/by/4.0). 